\title{
NOTES ON PRAETORS IN SPAIN IN THE MID-SECOND CENTURY B. C.*
}

This article reassesses the ancient evidence on the praetors who fought in the Spains in the $150 \mathrm{~s}$ and 140s, and argues against some recent reconstructions of the fasti praetorii for these years. In particular, two new possibilities are offered: L. Mummius, pr. in Hispania Ulterior 155 and prorogued through (at least) 154; and C. Laelius, $p r$. in a city jurisdiction in 145, and sent ex praetura to Citerior in 144, when his friend Scipio Aemilianus secured the removal of the Spains from the consular sortition for that year. If correct, this example of a city praetor setting out after the year of the magistracy for an overseas province would provide an early precedent for what was later to be a common practice, which Sulla as dictator finally was to institutionalize.

\section{INTRODUCTION}

We know rather little about the identities and even less about the activities of the praetors of the latter two-thirds of the second century '. Once Livy's continuous account gives out, so do the annual reports of praetorian elections and provinciae such as are found in his Books XXII (the year 216) through XLV (ending with 166). Three hundred ninety-six praetors will have been elected in the years 165-100. Only about one-quarter of the names of these men (not quite 100) come to us from direct attestation in the ancient sources of an individual praetorship, a promagistracy resulting from a praetorship, or praetorian rank. However, since virtually every consul must have been an

* Some of the arguments found here were proposed in my doctoral dissertation, The Praetorship in the Roman Republic down to 81 B. C., Harvard Univ., 1990. I must express my gratitude to Professor E. Badian, who directed the dissertation, for kindly commenting on several successive drafts of this paper. Prof. Badian's careful criticism and expert advice greatly improved this article, and I am very much indebted to him for a number of helpful suggestions. However, it should not be assumed that he agrees with all the opinions here expressed, and the responsibility for errors remains my own.

1 All dates are B. C. 
ex-praetor in the years following the lex Villia Annalis of $180^{2}$, we can identify with reasonable certainty about 85 additional Romans who held this office, working from the consular Fasti and from notices in literary sources concerning failed consular candidacies. On occasion, praetorian rank also may legitimately be inferred from details such as an individual's position on an embassy. More risky are inferences of praetorian status based on criteria such as an individual's service as a legatus in an important military command or status in the Senate. But all told, even on a generous reckoning, more than half of the praetors of 165-100 are lost to us; most of those who remain are only names, without firm dates. In fact, for no individual year in this period can we reconstruct an entire praetorian college, and seldom can we compile a list of a continuous series of praetors who held command in a particular prouincia. One important reason for this is that once real trouble developed in a prouincia-that is, exactly when we are likely to get information-it was typically declared consular.

Nonetheless, there are a few instances where we do have relatively complete information on a particular theater over a limited period of time. In particular, Appian's Iberica $(56,234-65,278)$ gives us the relative order of praetorian commanders in Spain in the mid- to late-150s and then 147-143 ${ }^{3}$. Because of the compressed nature of this source, these cases remain highly problematic. We are still quite far from a scholarly consensus on the chronology, identities and sometimes even exact names of the Spanish praetors in question. The aim of this paper is to reexamine this evidence on the sub-consular commanders of the Spanish wars of the mid-second century, and to offer a number of suggestions which may help us make better sense of our inadequate record.

We know nothing of the identities of Roman commanders in the Spains for about a decade after 166, the last year for which we have Livy. The silence is broken when Appian in his Iberica attempts to provide the background and main details of a major revolt in Lusitania and Celtiberia, which came to a head (so it seems) in the years 155-150. After omitting the events of two years

${ }^{2}$ On the lex Villia Annalis, see most recently R. J. Evans and M. Kleijwegt, ZPE 92 , 1992, pp. 181-195. Only P. Cornelius Scipio Aemilianus (cos. 147, II 134) is known to have reached the consulship without having held the praetorship in this period; his consular bid for 147 required a special SC (App. Lib. 112,531; Per. L). In 89 C. Iulius Caesar Strabo Vopiscus (aed. cur. 90) demanded a similar exemption in order to seek the consulship of 88 (Cic. Phil. XI 11 Caesar Vopiscus... ex aedilitate consulatum petit, soluatur legibus).

${ }^{3}$ The Appian passages and other sources relevant to the fighting in Spain in this period are collected in A. Schulten, Fontes Hispaniae Antiquae IV: Las Guerras de 154-72 a. de J.C., Barcelona 1937, pp. 1-31 and 96-117. I have discussed elsewhere (RFIC 121, 1993, pp. 153-184) a passage of Florus (II 7,7) which preserves the names of four "praetores" who were defeated in the First Slave War in Sicily in the mid- 130s. 
(149-148), Appian once again picks up his account with a detailed narrative of the major war with Viriathus (roughly, the years 147-139) and the struggle with Numantia (approximately 143-133). Appian also offers us our only continuous narrative for events in the Spains after the fall of Numantia down to the arrival of Sertorius in Iberia in 83 or 82 . But he presents the history of the prouinciae during this period in an extremely compressed summary ${ }^{4}$ : one-anda-half Teubner pages highlight selected moments in the half century 132-82.

Appian's account of the Spains in the years down to 133 seems to be organized geographically, by area of fighting. This division sometimes-but by no means always-coincides with the Roman administrative prouinciae, Hispania Citerior and Ulterior ${ }^{5}$. This means we cannot always surmise from Appian's organization what prouincia a given Roman commander held ${ }^{6}$. In this paper I am mostly concerned with the problems regarding the identity and chronology of the Spanish commanders in the years 157 through 153 and 147 through 142. Here real difficulties remain, despite the recent efforts of scholars such as Broughton, Simon, Astin, Sumner, Knapp and Richardson to make sense of the difficult ancient material ${ }^{7}$. Since there is general agreement on the

${ }^{4}$ Ib. $99,428-100,437$.

5 Events which physically took place in the eastern part of the peninsula (mostly Celtiberia) in the years $154-150$ are covered by $I h$. 44,180-55,233. Events in the western part (mostly Lusitania) in the period (as I will argue) 157-150 are contained in $I b .56,234$ 60,255 . At only one point $(59,247)$ does Appian bother to point up the chronological relationship of events in these two separate theaters to each other. At $I b$. 61,256 Appian skips to fighting in Lusitania in 147, and stays in that theater until the defeat and death of Viriathus in $139(\mathrm{Ib} .76,321) . \mathrm{Ib} .76,322$ is a clearly marked transition to the events in Celtiberia of 143; the main events of the Numantine war are then related down to the final settlement of 133 ( I b. 99,428).

${ }^{6}$ E.g. the activities in Lusitania of L. Licinius Lucullus (cos. 151 and pro cos. 150), who must be a commander in Citerior, are found in the (Lusitanian) section Ib. 59,247-248. And Spanish commanders of course crossed the notional provincial boundaries (cf. Liv. XXXII 28,11) and collaborated when the need arose (cf. Liv. XXXIX 30,1; XL 39,3 and 47,1). Thus L. Licinius Lucullus and Ser. Sulpicius Galba fought simultaneously (but not jointly) against the Lusitanians in 150 (Ih. 59,247-248) and M. Aemilius Lepidus Porcina and D. Iunius Brutus both acted against Pallantia in 137-136 (Ih. 80,350).

7 T. R. S. Broughton, The Magistrates of the Roman Republic [= MRR] I-III, New York 1950-1986; H. Simon, Roms Kriege in Spanien, 154-l33 v. Chr. [= Roms Kriege], Frankfurt am Main 1962; A. E. Astin, "The Roman Commander in Hispania Ulterior in 142 B. C.", Historia 13, 1964, pp. 247-254, and Scipio Aemilianus, Oxford 1967; G. V. Sumner, The Orators in Cicero's Brutus: Prosopography and Chronologv, Toronto 1973 [= Orators], and "Notes on Prouinciae in Spain (197-133 B. C.)», CPh 72, 1977, pp. 126-130; R. C. Knapp, Aspects of the Roman Experience in Iheria, 206-100 B. C. [= Roman Experience], Valladolid 1977; J. S. Richardson, Hispaniae: Spain and the Development of Roman Imperialism, 218-82 B. C. [= Hispaniae], Cambridge 1986. N. Rosenstein, Imperatores Victi, Berkeley and Los Angeles 1990, in the course of his general discussion of the consequences of military failure in Rome has occasion to comment on most of the praetors discussed here! In general, see also Z. W. Rubinsohn, "The Viriatic War and its Roman Repercus- 
identities (if not always the exact prouinciae) of the Spanish commanders of the years 151-150 and 141 through 133, I shall touch on these years only incidentally. In any event, the latter of these two periods is, strictly speaking, outside the scope of this study, since both prouinciae were entrusted exclusively to consuls (who regularly were prorogued in their commands). We do not know the names of any praetors who served in Spain in the years 141-132, or whether any praetors were sent at all.

\section{The Praetorian Commanders in Spain in the 150s}

It is particularly difficult to reconstruct the order of Roman commanders in Hispania Ulterior who fought against a Lusitanian rising during the years ca. 157-150. Appian tells the fullest story of this war. A leader of the Lusitanians, Punicus, defeated two Roman commanders, "Manilius» and "Calpurnius Piso», presumably (M.') Manilius and (L.) Calpurnius Piso (Caesoninus) (coss. 149 and 148 respectively) ${ }^{8}$. A total of 6,000 Romans were killed, including a quaestor Terentius Varro: it is unclear whether this was the result of one battle or several. Punicus followed up his victory, it is said, by ranging as far (west) as the Ocean - perhaps beyond the Roman prouincia of Hispania Ulterior. $\mathrm{He}$ secured the allegiance of the Vettones, in west central Spain; and then went on to besiege a people under Roman control, the so-called Blastophoenices («offspring of Phoenicians») 9 .

Punicus died in these operations, only to be succeeded by a certain Caesarus. Caesarus fought against a Roman praetor, «Mummius», who brought a new army. This man should be L. Mummius, the consul of $146^{10}$. Mummius spoi-

sions», RSA 11, 1981, pp. 161-204; A. Montenegro Duque, «Las guerras de Lusitania (155138) y Celtiberia (155-133)", in España romana (218 a. de J.C.-414 de J.C.) = Hist. de España dirigida por R. Menéndez Pidal $\mathrm{II}_{3}$ 1, Madrid 1991, pp. 81-118.

${ }^{8} \mathrm{Ib}$. 56,234 . No other Manilius is known to have reached a magistracy in this general period of the Republic other than the consul who commanded the land forces in the first year of the Third Punic War, in 149. No Calpurnii Pisones offer themselves as plausible candidates for a praetorship in the mid-150s other than the cos. 148, L. Caesoninus. The fact that M.' Manilius and L. Caesoninus held consecutive consulships and commands in a major war lends support to the hypothesis of a "Spanish connection», whether they served together or consecutively in Spain.

$9 \mathrm{Ib}$. 56,235 (with the story of their origin-from Punic settlers brought from Africa by Hannibal). There is no reason to identify these people with the Bastuli of the south coast of Iberia, as was suggested by E. Hübner, $R E$, s.u. Bastetani, col. 113. It seems from Appian's context that the Blastophoenices were on the Ocean (i.e. southwest Iberia).

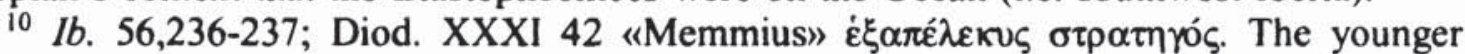
brother of $L$. Mummius, Spurius, was probably of praetorian rank by $144 / 3$, when he was sent as a member of a high-ranking embassy to the east (the other members of the legatio 
led his initial success against Caesarus, losing in a disorderly pursuit 9,000 troops (out of a force of 14,000) as well as his camp, which he had filled with enemy plunder. This was a major disaster, and (as matters turned out) a conspicuous one: the barbarians carried the captured Roman standards throughout "all of Celtiberia" ". Photius' summary of Diodorus places the defeat of the

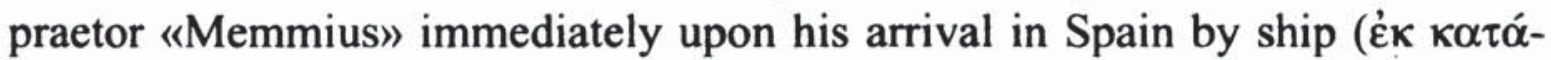
$\pi \lambda \circ v)$, and states that the news of this rout changed the opinion of the Aravaci in north central Spain toward Roman military might; the Lusitanians' (unexpected) defeat of the praetor was the chief reason the Arevaci voted to revolt from Roman rule ${ }^{12}$. To return to Appian. Mummius avoided committing his 5,000 remaining soldiers to further battle with the enemy until he had restored discipline. We are not told how long he took to retrain his troops; one would imagine at least a few months. As Appian tells the story, the Roman commander waited until he was able to attack the Lusitanians as they passed by on level ground and in this way regained his lost booty and standards ${ }^{13}$.

Now the Lusitanians on the other (south) side of the Tagus, under the leadership of one Caucaenus, attacked the Cunei (= Conii, who were Roman allies) and captured their principal city Conistorgis. The rebel band then split into two groups. One ravaged far and wide in (North) Africa, the other centered on the North African city of Ocile ${ }^{14}$. L. Mummius chose to follow them to Africa with an enhanced force of 9,000 infantry and 500 cavalry (suggesting that he had spent some time recruiting native auxiliaries), and managed to inflict a defeat on both portions (so it seems) of the Lusitanian force, as well as to raise the siege of Ocile.

being P. Cornelius Scipio Aemilianus, cos. 147, and L. Caecilius Metellus Calvus, cos. 142). On the date of this embassy, see H. B. Mattingly, $C Q 36,1986$, pp. 491-495, persuasively arguing against the traditional date of $140 / 39$ (for which see $M R R$ I, p. 481 with n. 2). Sumner (Orators, p. 45) points out that Spurius is included by Cicero among aequales of C. Laelius (pr. 145 and cos. 140), and P. Scipio Aemilianus (cos. 147 at age 37 or 38, under the legal age) (De Amic. 101). It thus seems unlikely that Sp. Mummius held the praetorship in the mid-150s: his famous brother is in any case the obvious candidate.

"Ib. 57,237 .

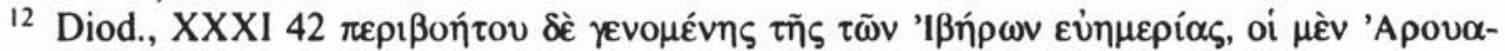

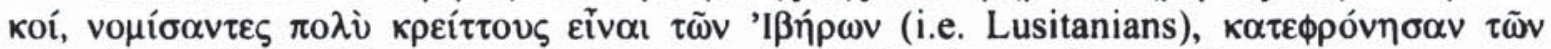

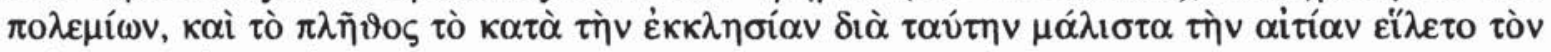

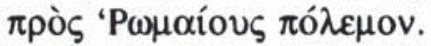

${ }^{13} \mathrm{Ib}$. 57,238 . The standards were surely in the process of being sent around the tribes to be shown off, as Appian implies (56,237 fin.).

14 J. Schweighäuser (Appiani Historiae Romanae III, Leipzig 1785) ad Ib. 57,240 found

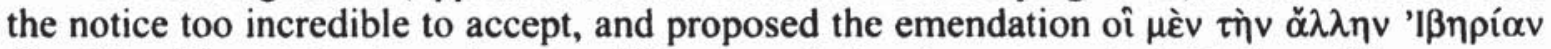

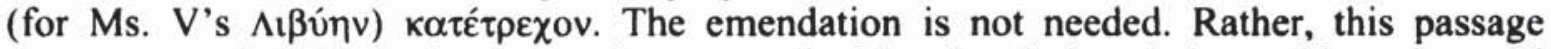
demonstrates that Appian's account is very much abbreviated: the rebels would need a good bit of time to get from south of the Tagus to the north coast of Africa (some 250-350 miles). On the location of Ocile (= Arzila in Morocco), see Rubinsohn, RSA 11, 1981, p. 184, n. 120. 
Appian states that this success earned Mummius a triumph ${ }^{15}$. Unfortunately the Fasti triumphales break off after reporting two consular triumphs in 155 and are not preserved for the next twenty-five years, so we cannot check whether this is accurate. In the absence of conflicting evidence, Mummius' triumph should probably be accepted, since it helps to explain how a man whose family had not advanced beyond the praetorship landed the consulship and a major command against the Achaean League in $146^{16}$.

We are told that L. Mummius was succeeded by a M. Atilius ${ }^{17}$, who captured Oxthracae, the chief Lusitanian city (location unknown) and thereby frightened all the neighboring tribes into submission, most notably the Vettones. But Atilius' success was short-lived. A fresh revolt broke out immediately after he went into winter quarters, and Roman subjects were again soon hard pressed by the rebel tribes ${ }^{18}$.

The next Roman commander in Lusitania was Ser. Sulpicius Galba, who Appian specifically says replaced M. Atilius ${ }^{19}$. Since here we are establishing only the relative chronology of the Roman commands in Spain, we need not go into all the details of his infamous tenure in this theater. It is clear that he spent two campaigning seasons in Ulterior, the first of which was quite unsuccessful. Immediately after arriving in his prouincia, he met a setback almost as serious as that of Mummius, losing 7,000 men at the hands of the Lusitanians. Galba withdrew to southwest Spain and wintered at Conistorgis ${ }^{20}$. At

15 Ib. $57,239-243$.

${ }^{16}$ He must be the son of L. Mummius, pr. 177. Velleius Paterculus $\left(I_{13,2 ;}\right.$ II 128,2) is wrong to call him novus. Degrassi (Inscr. Ital. XIII 1 p. 557) accepts Appian's notice of his triumph.

${ }^{17}$ It is likely that this man is a Serranus: no Atilii Reguli are found in office after the pr. 213. There is a moneyer M. Atilius Serranus attested just after this time, dated by M. H. Crawford to 148 (Roman Republican Coinage [ $R R C$ ], Cambridge 1974, I, pp. 254-255, n. 214), but it is certain that he was not the praetor in Spain. There are several options for the parentage of the $p r$. in Spain (if a Serranus): 1) first-born son of the M. Serranus who was pr. 174, and older brother of Sex. (M.f. C.n.) Serranus (cos. 136). 2) son of C. Serranus, pr. 185. 3) son of A. Serranus, pr. 192 (II 173) and cos. 170. There is no basis on which one can choose among these options: of course, he may be the son of an Atilius we do not hear of elsewhere. The "Serranus" who shows up as legatus in command of the fleet in Africa in 147 (App. Lib. 114,543) is probably the Spanish praetor (rather than Sex. Atilius, cos. 136). The position was occupied the previous year by a man who must be a praetor or praetorius, L. Hostilius Mancinus, the future cos. 145 (MRR I, p. 462).

18 App., Ib. 58,243-244.

19 Suetonius, Galba 3,2 reports that Galba obtained Hispania ex praetura, probably an anachronistic statement based on the later practice (F. Münzer, RE, s.u. Sulpicius 58, col. 761). It is well before the point where we would actually expect regular prorogation of city praetors in overseas prouinciae, after the addition of a praetor repetundis in 123 . Yet on C. Laelius (pr. 145, pro pr. in Citerior 144) see below in text.

${ }^{20}$ Ib. 58,244-46; cf. Per. XLVIII; Oros., IV 21,3. 
this point Appian provides us with our first synchronism between the praetors in the west and the consuls further east. When Ser. Sulpicius Galba was in winter camp at Conistorgis, (L. Licinius) Lucullus (cos. 151) was wintering in Turdetania. The first year of Galba's command then should date to 151 . The notorious events of his second year, in which he massacred 30,000 Lusitanians, will be discussed after we examine Appians's narrative of fighting in Celtiberia during this same period.

By 154 Segeda, the chief city of the Celtiberian Belli, had forced its smaller neighbors, including towns which belonged to the tribe of the Titti, to settle in its territory, and had started to surround its now-enlarged settlement with a strong wall-in violation of a treaty made with Ti. Sempronius Gracchus ( $p r$. 179 ) in 178. The Senate ordered the wall to be pulled down, and rescinded the town's long-standing exemption from tribute and military obligations. Segeda disobeyed the Senate's orders, placing themselves de facto in a state of rebellion. A consul of 153, Q. Fulvius Nobilior, was sent to Spain with nearly 30,000 men to move against the town. The Segedans did not finish their fortifications, but simply decamped and joined forces with the Aravaci (who must already have been in rebellion) ${ }^{21}$.

Q. Fulvius Nobilior was to fight against Celtiberians, and so must have received Hispania Citerior, and not Ulterior, as his prouincia-the first time that one of the Spains had been designated consular since the year 195. This move must have been taken in principle in 154, to judge from the Roman decision to change the beginning of their administrative year from March 15 to January 1 , starting for $153^{22}$. In view of the recent losses of M.' Manilius, Calpurnius

${ }^{21}$ Ib. 44,180-45,185; for Ti. Gracchus' treaty, see Liv., XL 50,5 with Per. XLI; Plut., Ti. Gracch. 5,5.

22 Richardson, Hispaniae, p. 134. The Periocha of Livy XLVII (which covers the years 159 through 154) notes praeterea res in Hispania a compluribus parum prospere gestas continet, followed by a notice of the change of the beginning of the consular year (from 15 March) to 1 January: mutandi comitia causa fuit, quod Hispani rebellabant. Cassiodorus (Mon. Germ. Hist. IX 2, p. 130) gives a similar notice, under the Varronian year 601 (= 153): hi primi consules Kal. lanuariis magistratum inierunt propter subitum Keltiberiae bellum; see also Fasti Praenestini (Inscr. Ital. XIII 2, pp. 110f) ann]us nol [uus incipit] quia eo die mag. ineunt, quod coepit $[$ [p.R.] c.a. DCI. It seems amazing that a rising in Celtiberia (not Lusitania, it will be noticed) in itself was thought enough to explain a major calendar reform. Such a measure must have been planned some time in advance. For one thing, it would truncate the tenure of the magistrates currently in office by two and one-half months. It is a pity that we know nothing of the relationship of the solar and the official calendar in the years after 168, in which the official calendar was 68 days in advance of the solar calendar (Liv. XLIV 37,8 with P. S. Derow, Phoenix 27, 1973, pp. $345 \mathrm{ff}$, esp. 346, n. 4 , and 356; but on patterns of intercalation in the second century, see V. M. Warrior, Latomus 50, 1990, pp. 80-87). We simply do not know whether in the period after 168 the official year remained so much in advance of the solar year. Derow suggests the gap actually grew (op. cit., pp. 355-356), but his hypothesis is quite speculative, and need not 
Piso and (perhaps) L. Mummius, it is surprising that the consul was not sent against Lusitani. However, the mixed Roman record in Lusitania was a catalyst to (more serious) revolt in Celtiberia. As we have seen, the Aravaci are said to have watched with interest the success of the Lusitanians against L. Mummius. And the Lusitani were highly mobile, crossing even across the straits to Africa. The Senate may have felt that Nobilior's presence in Citerior would ensure that these guerilla-bands kept their operations localized in the southwest of the peninsula where a praetor could be responsible for the chase. It was important that the Lusitani not attempt to join up with the dissatisfied tribes of central Iberia ${ }^{23}$. But neither this danger nor Segeda's synoecism of the Belli and Titti seem sufficient to motivate the Senate's decision to declare Citerior consular; and both Appian and Diodorus make it clear that the inhabitants of Segeda had not actually raised arms until after the formal declaration of war in Rome ${ }^{24}$. We must conclude that the Aravaci had risen in open revolt by late 154 . A rebellion by a major Celtiberian tribe, combined with the activism of Segeda, would make the sending of Q. Fulvius Nobilior explicable.

The consul Q. Fulvius Nobilior was in his prouincia by August 153. Quite soon after his arrival, he met military disaster, followed by a tough winter-and supersession ${ }^{25}$. His successor, M. Claudius Marcellus, cos. III 152, also spent

be accepted. At any rate, it is impossible to believe that a sudden decision was made to move the consular year back 74 days simply when an emergency arose in Spain. A most tentative suggestion. The change of calendar had been planned for some time, with the idea that it would be instituted in the first year of the seventh saeculum of Rome (thus P. Brind' Amour, Le calendrier romain, Ottawa 1983, p. 131). There was no accepted date for the founding of Rome at this time (see E. Bickerman, Chronology of the Ancient World (rev. ed.), London 1980, pp. 77f.). The anniversary year can have been 153, as Brind' Amour has it, pointing to an extract from the calendar of M. Fulvius Nobilior, father of the cos. 153 (Macr. Sat. I 13,21, where $191=$ A.U.C. 562). But the years 152 or 151 are possible-or even 150 (Bickerman, loc. cit.). The statement of the Periocha (mutandi comitia causa fuit, quod Hispani rebellabant) admits the interpretation that a serious revolt in Celtiberia prompted the Romans to modify their anniversary plans, and the change in calendar was taken up a year or so early. In any event, there must be something more to the background of the designation of Citerior as a consular prouincia than Richardson's view that «at least one consul each year seems to have expected a war to fight, and in the middle of the second century there was some difficulty in fulfilling this need" (Hispaniae, p. 135, followed by L. A. Curchin, Roman Spain: Conquest and Assimilation, London and New York 1991, p. 34).

${ }^{23}$ There is no good evidence that the Lusitani had ever gone very far into Citerior by 153. We have seen (Note 9) that Punicus' attack on the Blastophoenices was probably quite far from this prouincia; and the alleged carrying of the standards throughout "all of Celtiberia" (which must have preceded the consul's arrival), would not justify the declaration of Citerior as a consular prouincia.

${ }^{24}$ Ib. 44,180-183; Diod., XXXI 39; Richardson (Hispaniae, p. 133) rightly notes that «even in the version given by Appian, the decision of the Senate seems rather abrupt».

${ }^{25}$ App. Ib. 45,184-47,197. For the terminus ante quem for Q. Nobilior's arrival in the prouincia, see $I b .45,187$, where Appian states that Nobilior (soon after coming to the 
only one year in Spain, and was replaced by L. Licinius Lucullus, cos. $151^{26}$. It will be remembered that only with $\mathrm{L}$. Lucullus can we establish a synchronism with what was happening in western Iberia: L. Licinius Lucullus and the praetor Ser. Sulpicius Galba spent two full campaigning seasons together in Spain (151 and 150) ${ }^{27}$.

Something should be said about the «Livian» evidence for the Spains in these years. Periocha XLVII offers little help for the problem of the Roman commands. It places the notice of the defeats inflicted on several (complures) commanders in the praeterea section; and so these setbacks can have taken place in either Spanish prouincia any time between 159 through 154, the span of Livy Book XLVII. Obsequens XVII (for 154) reports $a$ Gallis et a Lusitanis Romani per arma grauiter uexati. Unfortunately we do not have Obsequens for 155 . He may have reported the same thing (or something similar) for that year.

Eutropius, however, may have something to supplement the accounts of Diodorus and Appian. Eutropius reports Prusias etiam filium suum Nicomeden senatui commendauit. Insequenti anno L. Mummius in Lusitania bene pugnauit. Marcellus postea consul (= M. Marcellus, cos. III 152) res ibidem prospere gessit (IV 8,2-9). There is some confusion here. Prusias is said to have taken his son Nicomedes to Rome in $167^{28}$; Mummius of course did not win his successes «in the following year", which would be 166 ! But Nicomedes spoke in the Senate in 156 on behalf of his father ${ }^{29}$, which brings us closer

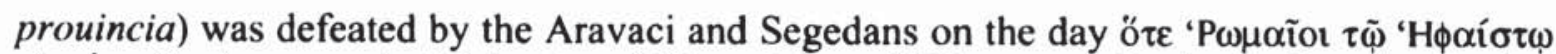

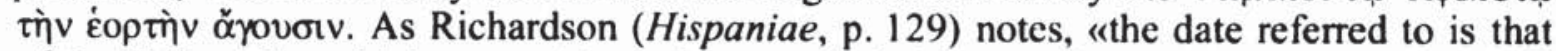
of the Vulcanalia, which was celebrated on viii Kal. Sept., so that Nobilior's arrival should be placed about the beginning of August, despite the early date of his entry into the consulship». We shall make use of this date shortly.

${ }_{26}$ M. Claudius Marcellus, who had experience in Spain (as pr. for «Hispania» 169) was able to get the Belli, Titti and Aravaci to send envoys to Rome concerning peace, only to have the Senate decide to continue the war (Ib. 48,198-49,208; cf. Polyb., XXXV 2,1-2, with F. W. Walbank, A Historical Commentary on Polybius III, Oxford 1979, pp. 640-647). Sources for Lucullus' command can be found in MRR I, pp. 455 and 456.

${ }^{27}$ Sumner $(C P h 72,1977, \mathrm{pp} .129 \mathrm{f})$ has suggested that each of these three consuls was allotted the prouincia of "Hispania», on the basis of his view that the division of Spain into Hispania Citerior and Ulterior was not effected until 133. Sumner did not attempt to explain what prouincia the praetorian commanders who served in Spain at the same time as these consuls received. I will treat the improbability of Sumner's view on the "non-division" of Spain in a projected study; let it suffice for now to point out that Livy explicitly tells us that in 197 the Senate ordered the first regular praetors to be sent to the Spains to demarcate the border between what would comprise Hispania Citerior and Ulterior (XXXII 28,11 ). It would be most strange for the praetors to disobey that order, and for us not to hear of it.

${ }^{28}$ Liv., XLV 44,4f.

${ }^{29}$ Polyb., XXXII 16,4. 
to the time in which L. Mummius must have held his command. Eutropius is very likely to have amalgamated Prusias' and Nicomedes' missions; the statement insequenti anno L. Mummius in Lusitania bene pugnauit is simply an epitomator's phrase, which poses no real difficulty. We have seen Mummius was unsuccessful at first, but ultimately won a triumph, and Eutropius (in his severe summary) gives only the final outcome. This passage should place Mummius in Spain in the year 155.

This is all the evidence we have to approach the problem of the Lusitanian commands of the praetors M.' Manilius, L. Calpurnius Piso, L. Mummius and M. Atilius (Serranus). Wilsdorf ${ }^{30}$ was convinced that M.' Manilius and L. Calpurnius Piso were successive governors of Ulterior in 155 and 154. De Sanctis and Simon suggested that M.' Manilius and L. Piso were governors of Citerior and Ulterior respectively in 154 and that Appian, in his report of Roman operations against Punicus, is referring to a single battle waged by the two praetors in concert ${ }^{31}$. Modern authorities appear to be unanimous in placing L. Mummius in Hispania Ulterior as praetor in 153, that is, simultaneous with the command of the consul Q. Fulvius Nobilior in Citerior. None of these views should be regarded as certain.

M.' Manilius and L. Calpurnius Piso probably should be successive commanders in Hispania Ulterior. It is unlikely that Punicus and the Lusitanians at the earliest stage of their rebellion would attract the attention of the Roman commanders of both Ulterior and Citerior, and then defeat them in a single pitched battle. Even in the well-attested period 197-167, we find only one joint campaign between the praetors of the two prouinciae - in Hispania Citerior ${ }^{32}$. It does not make strategic sense for the Romans to fight the guerilla-bands of the Lusitanians in their mountainous country with a united force led by two praetors ${ }^{33}$.

L. Mummius should have directly succeeded L. Calpurnius Piso in Ulterior. Appian's narrative states that $\mathrm{L}$. Mummius had a victory and then a major defeat against the Lusitanians, retrained his troops, waited until he could attack the rebels on favorable terrain, and then, after almost doubling his force, chased the Lusitanian tribes hundreds of miles to Africa, where he raised a siege and won at least two major battles, thus earning himself a triumph-all, it is implied, in the space of a year! This is too much to believe: L. Mummius must

${ }^{30}$ D. Wilsdorf, «Fasti Hispaniarum provinciarum», LSKPh I, 1878, pp. 95f. Wilsdorf's view has been accepted by Broughton (initially) in MRR I, pp. 448 and 450, Knapp, Roman Experience, p. 195 and Richardson, Hispaniae, p. 185.

${ }^{31}$ G. de Sanctis, Storia dei Romani IV 1, Turin 1923, p. 466; Simon, Roms Kriege, pp. 13-14; Sumner, Orators, p. 62; Astin, Scipio Aemilianus, p. 37, n. 2; MRR III, p. 134.

32 In 185 the praetors L. Quinctius Crispinus and C. Calpurnius Piso united their forces to campaign in Carpetania (Liv. XXXIX 30, Iff).

${ }^{33}$ See Strabo, III 3,8, pp. 155-156, on the nature of this people and their region. 
have had a command in Ulterior for more than one campaigning season. In the first year, it appears, Caesarus and his Lusitanians killed 9,000 Romans in battle, and then passed Roman standards throughout «all of Celtiberia». L. Mummius must then have withdrawn into winter quarters, where he retrained his 5,000 remaining men. In his second season Mummius regained his standards, defeated the Lusitanians in Africa, and rescued Ocile from siege. His triumph may even have had to wait until the next consular year (i.e. two years after his praetorship). The fact that $\mathrm{L}$. Mummius had suffered a serious defeat in the first year in his prouincia does not exclude the possibility that he was prorogued. Ser. Sulpicius Galba (pr. 151) lost almost as many men to the Lusitanians, early in his year of command, but all the same his imperium was extended into 150 .

It may be relevant to the chronology that Photius/Diodorus has Mummius arrive with his force in Lusitania by ship, a rare practice for commanders for the Spains ${ }^{34}$. The fact Mummius had to sail to his prouincia may imply the date 155 or early 154 , when we know two transalpine Ligurian tribes, the Oxybii and Deciatae, had made the coast-road along the Riviera particularly hazardous, hemming in the people of Massalia and besieging their colonies Antipolis (Antibes) and Nicaea (Nice). Following the request of a Massaliote embassy for help, the Senate in 154 sent three legati to beg off the Ligurians, one of whom was wounded when he came to shore. This incident prompted the sending of Q. Opimius (cos. 154) with an armed force, who quickly defeated the two Ligurian tribes and through stern measures restored peace to the area ${ }^{35}$. Opimius' victory will have made the Riviera coast safe, for a time: it is difficult to see why L. Mummius would have to sail in 153. At any rate, we have observed that Eutropius suggests L. Mummius was in Spain in 155, and that is the date I adopt for this praetor's appointment.

We still need to account for Diodorus' statement that the disaster which befell the praetor «Memmius» on his arrival in Lusitania influenced the Aravaci to revolt from Roman rule, and also the declaration of Citerior as a consular prouincia for 153, which led to the Segedans' decision to leave their territory and join the Aravaci. I would argue this sequence of events may have taken upwards of 15 months, i.e. summer 155-fall/winter 154/153.

34 Schulten, Fontes IV, p. 99.

${ }^{35}$ Polyb., XXXIII $8-10$, esp. 8,1 on the Massaliotes in $154<0 і ̈>\pi \alpha ́ \lambda \alpha ı$ $\mu \grave{\varepsilon} v \kappa \alpha \kappa \omega \tilde{S}$

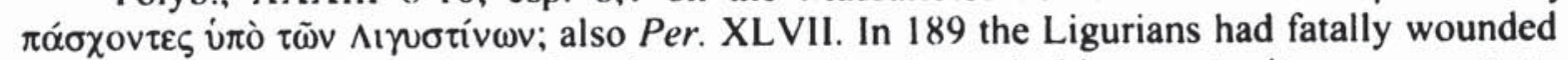
the praetor L. Baebius Dives when he was passing through this very territory, en route to his prouincia of Ulterior (Liv., XXXVII 57,1-2; Oros., IV 20,24). On the difficulties the Ligurians posed to the land route from Italy to Spain, see Schulten, Fontes IV, p. 10, cf. p. 50; Walbank, Commentary on Polybius III, pp. 549-553; C. Ebel, Transalpine Gaul, Leiden 1976, pp. 59-63. 
It would be helpful to know at what time of the year L. Mummius first reached his prouincia. The fact that Mummius was coming with a new army ( $\mu \varepsilon \tau \grave{\alpha} \sigma \tau \rho \alpha \tau i \tilde{\alpha} \zeta \grave{\alpha} \lambda \lambda \eta \zeta)$ ) may in itself suggest a late arrival. Rome had difficulty conscripting troops for the Spains as early as the 180s ${ }^{36}$; service in the Spains was even less attractive in the 150s: «the campaigns were against the comparatively poor highland and inland communities, already bled of much of their resources by long wars with Romes ${ }^{37}$. The defeats and large losses of the praetors M.' Manilius and L. Piso will have underscored the dangers of fighting in this theater. In 153, when the consul Q. Fulvius Nobilior brought his new army (albeit twice the size of Mummius'), he appears to have arrived in Spain only in August-eight months after his entry into office. Recruitment problems had pushed back consuls' departure dates in the past ${ }^{38}$, and are enough to explain Nobilior's delay. Of course, matters would come to a head in the year 151, when the recruiting problem for Spain led to serious public disorder ${ }^{39}$. L. Mummius, entering office (surely) still under the old system of March 15, had to levy a force (perhaps the strength of two legions), and find transports for them. In the face of these difficulties, he may not have reached Lusitania until June or July-or perhaps later. One might add that a delayed departure from Italy, not unlikely in itself, would help explain this man's (almost certain) prorogation.

The news of the Aravaci deciding to revolt, reported by Photius/Diodorus, is likely to have reached Rome only some time after the consuls of 154 took office. If it were known at the beginning of the administrative year that Mummius' defeat had sparked a rebellion of a major tribe clear across the Iberian peninsula, I find it difficult to believe the Senate would retain that praetor in his command. Photius/Diodorus gives no indication of the temporal connection between the two events. It need not have been all that close. We must allow

${ }^{36}$ Liv., XXXIX 38,8-12 with L. R. Taylor, JRS 52, 1962, p. 21; cf. Liv. XLII 18,6 (172).

37 Astin, Scipio Aemilianus, p. 166.

38 E.g. Liv. XXXIX 29,10 (185). Cf. the list in Astin, Scipio Aemilianus, p. 168, n. 3.

39 See Polyb. XXXV 4,1-6 for unprecedented difficulties in recruiting an army for Spain in 151; Per. XLVIII, reporting that the consuls of 151 were jailed by tribunes cum dilectum severe agerent; App. Ib. 49,209 for the necessity of a lot that same year to determine which recruits were to receive less difficult service. The best discussions of the recruitment problems of this time are Astin, Scipio Aemilianus, pp. 42f and 167-172; P. A. Brunt, Italian Manpower, Oxford 1971, pp. 397f; J. K. Evans, «Resistance at Home: The Evasion of Military Service in Italy during the Second Century BC", in Forms of Control and Subordination in Antiquity (edd. T. Yuge and M. Doi), Leiden 1988, pp. 121-140. W. V. Harris, War and Imperialism in Republican Rome, 327-70 B. C., Oxford 1979, pp. 49f, relying on Polybius loc. cit., speaks with confidence of «the time of changing attitudes which began in 151». Harris however ignores Polybius' rhetorical purpose in this passage, on which see F. W. Walbank, A Historical Commentary on Polybius III, Oxford 1979, p. 646. 
time for the details of a rout in Lusitania to become known in Celtiberia, and for the Aravaci to sound out the attitudes of their neighbors and allies-they could hardly hope to take on Rome alone-before their decisive step of calling a public assembly to vote on the matter of going to war. The Diodorus epitome states that the Lusitanian victory was the chief reason the Aravaci chose to

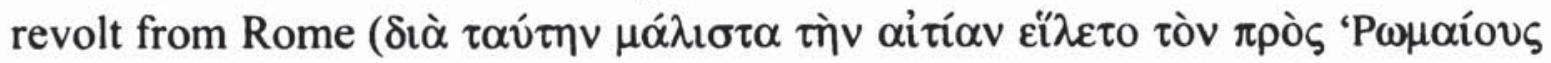
$\pi$ ó $\lambda \varepsilon \mu o v)$, implying that there was some deliberation, with other factors being taken into account. Photius/Diodorus in fact may be summarizing a process which took no little time. We should remember this source had compressed Mummius' initial fighting against Caesarus to make it seem as if the Roman force was ambushed as it landed: even the cursory Iberica mentions a victory, and then a defeat in the pursuit. At any rate, the revolt of the Aravaci must have contributed to the Senate's decision to send out a consul for 153, under a new administrative calendar, and hence is best dated to 154 . The Segedans can have left their territory any time after learning that Citerior was to be declared consular (for the first time in 42 years), and so as early as fall/winter 154. We need not suppose they waited to see who was allotted the prouincia, or for the consular army to start on its actual march.

The background to Mummius' decision to pursue the Lusitanians into North Africa may be precisely the new arrangement for 153 . If the Senate was sending not just a consul to Hispania Citerior, but also a successor (i.e. the praetor M. Atilius) to Mummius in Ulterior, Mummius may have gambled for a triumph. The change of the calendar added a special urgency to Mummius' campaigning. Consular 154, which began on 15 March 154, was only nine and one-half months long, since the start of the next consular year was 1 January 153.

A reconsideration of the evidence on the Spains in the 150s suggests the following series of commanders in Hispania Ulterior. First, M.' Manilius, $p r$. 157 (the previous year is also possible); L. Calpurnius Piso, pr. 156; and L. Mummius, pr. 155 and prorogued through 154 (returning from Spain perhaps at some time in 153). A two year command for this man is virtually certain, pace Appian. Mummius' successor, M. Atilius (Serranus), should be pr. 153. According to Appian, Atilius did quite a lot in his prouincia. He took the chief city of the Lusitanians, and forced all their neighbors to come to terms, including the powerful Vettones-only to have his arrangement fall apart when he went into winter quarters. The fact Appian mentions only one winter for Atilius does not preclude a command of two years, i.e. $p r$. 153 (arriving late, with the consul Q. Fulvius Nobilior), and prorogued through 152, with the peace he imposed failing in winter 152/151. There is no doubt that Appian's account is very much condensed: he also gives only one winter to Ser. Sulpicius Galba, 
$p r$. 151, who we know was prorogued through $150^{40}$. All we know of the commands in Citerior is the series of three consuls: Q. Fulvius Nobilior (cos. 153); M. Claudius Marcellus (cos. III 152); and L. Licinius Lucullus (cos. 151 and pro cos. 150) ${ }^{41}$.

\section{The Roman Commanders in Spain, 147-144}

Appian's account (our only detailed continuous narrative) leaves us in the dark as to what happened in the Spains in the period immediately following the commands of L. Licinius Lucullus (cos. 151 in Citerior) and Ser. Sulpicius Galba ( $p r$. 151 in Ulterior) in 151-150. Our next certain date and command is that of Q. Fabius Maximus Aemilianus, who set out to Hispania Ulterior to fight Viriathus as consul in 145, and was prorogued through $144^{42}$. Yet the sources record a total of five men (all of whom Broughton lists as praetors) who fought with the Lusitanian chief before the successes of Fabius, who as pro cos. is said (tantalizingly) to have been "the second man to defeat Viriathus" ${ }^{43}$.

Appian asserts that «not long after» Ser. Sulpicius Galba was able to avoid condemnation for his misdeeds in Spain (i.e. 149), a «C. Vetilius" was sent from Rome to check a Lusitanian inroad into Turdetania ${ }^{44}$. That he was a praetor seems certain: the Livian Periocha, Orosius and Diodorus all give him this title ${ }^{45}$. On arrival in Spain, Vetilius at first met with success when he

40 MRR I, pp. 456-457. The (unsuccessful) proposal for his trial for misconduct in Spain, which Appian notes at $I b .60,255$ (i.e. what seems to be the year 150), came only in 149 (MRR I, p. 459, under L. Scribonius Libo, tr.pl.; on the date, see esp. Cic. ad Att. XII 5b with Oxy. Per. XLIX).

41 A reconstruction of these commands - and the praetorian commands of the 140 s to be discussed below - is given in tabular form in Appendix A.

42 Ib. 65,273-278; Oxy. Per. LII.

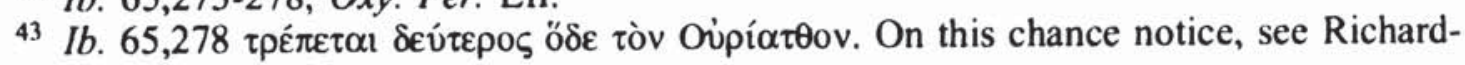
son, Hispaniae, p. 189.

${ }^{44}$ Ib. 61,256-257.

45 No two of our other sources who mention this man agree on the name. Per. Lll has M. Vetilium [several MSS. read "Velium»] praetorem (Jahn prints «Vatilius»); Orosius (V

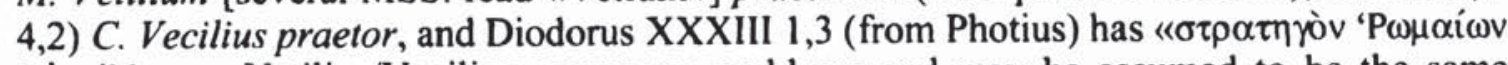
ờı $\hat{\lambda}^{\prime} \lambda$ เov»". Vetilius/Vecilius causes no problems and may be assumed to be the same tradition: $t(i) / c(i)$ is a very common confusion in MSS (e.g. -tius/-cius; also Atilius/Acilius; Attius/Accius, etc.). Diodorus, who was writing only a century later than this man's activities, must already have seen "Vetilius" in his source (or possibly "Vitellius", which is a fairly easy and common corruption). The mistake "Vitellius" may not be Diodorus' own misreading, but his epitomator's, who was compiling his work long after the Imperial Vitellii had become famous. The nomen Vetilius (which, in fact, is generally accepted for this man) is quite rare. The only known bearer of this name in the Republic is the P. Vetilius who was a relative of Sex. Aebutius (Cic. Caec. 24, with no indication that he was a senator). 
killed a number of Lusitanian foragers and then penned in the rest of their band ${ }^{46}$. Nevertheless, thanks to a ruse devised by Viriathus, the Lusitanians were able to escape to the town of Tribola (to the south of Urso, modern Osuna) ${ }^{47}$. When Vetilius chased in pursuit, Viriathus ambushed his force, captured the «old and fat» Roman commander, and put him to death ${ }^{48}$. Matters soon became worse. Though a quaestor managed to get 6,000 men to safety at Carpessus ${ }^{49}$ on the coast, once he was reinforced by the Belli and Titti (now Rome's allies) he dared to engage Viriathus - with unhappy results. The quaestor was forced to keep quiet in Carpessus, waiting for help from Rome; Viriathus ravaged Carpetania - just one of many indications that this war really cannot be localized to Hispania Ulterior ${ }^{50}$.

Appian reports that a C. Plautius was the next Roman commander to face Viriathus in the field, bringing from Rome 10,000 infantry and 1,300 horse. C. Plautius is sure to have been a praetor, in view of the size of his force: he was the direct successor to the command of Vetilius ${ }^{51}$. His identity, however, is utterly uncertain ${ }^{52}$. After Plautius lost twice in quick succession to Viriat-

46 See perhaps Oxy. Per. LI for $147[$ Lu]sitani subacti.

47 For Tribola, see A. Schulten, "Viriathus», $N J 39-40,1917$, p. 219. Knapp (Roman Experience, p. 202) considers the first man to "defeat" Viriathus (cf. $I b .65,278$ ) to have been Vetilius. This cannot be right, since Viriathus came on the scene as a leader of the Lusitanians only as a result of his successful plan to escape to Tribola, as Appian makes clear (Ib. 61,257-62,264).

48 Ib. 63,266, which includes the physical description; Diod., XXXIII, 1,3; Per. LII; cf. Oros., V 4,2 («C. Vecilius» escapes).

${ }^{49}$ Appian ( $\left.I b .63,267\right)$, in his eagerness to bring in the story of old king Arganthonius (see F. Cauer, RE, s.u. Arganthonius, col. 686) has identified Carpessus (= Carteia) with the extinct Tartessus, a common mistake (E. Hübner, RE, s.u. Tartessus, col. 1619; cf. Strabo, III 2,14, p. 151, Mela, II 6,8; Plin., $N H$ III 1,3).

${ }^{50} \mathrm{Ib}$. 63,267-268. Viriathus' wide ranging campaigns are well illustrated by the map in H. Gundel, RE s.u. Viriatus, coll. 209-210. See also Florus, I 33,15 [Viriathus] per quattuordecim annos omnia citra ultraque Hiberum et Tagum igni ferroque populatus (counting his years as a brigand as well as war leader); cf. Oros., V 4,2, obviously from the same source (Livy), who telescopes the predations of Viriathus a bit: siquidem Hiberum et Tagum, maxima et diuersissimorum locorum flumina, late transgredienti et peruaganti $C$. Vecilius praetor occurrit. Viriathus had probably not gathered a sizeable force until after his victory over Vetilius (cf. App. Ib. 62,264). Note that when his fortunes were on the wane in 139 Viriathus treated with both the commanders of Hispania Citerior, M. Popillius Laenas, and Hispania Ulterior, Q. Servilius Caepio (Diod., XXXIII 19; De Vir. Ill. 71,2).

${ }^{51} I$ Ib. 64,269. For Plautius' title, Per. LII; Oros., V 4,3; Diod. XXXIII 2 ò $\dot{\varphi} \varphi \alpha \pi \varepsilon ́ \lambda \varepsilon \kappa \psi \varsigma$

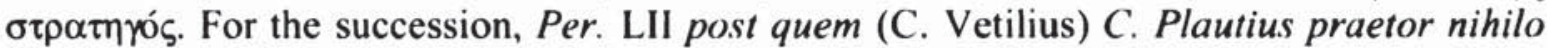
felicius rem gessit; Oros., V 4,3 deinde (after C. Vetilius) C. Plautium praetorem idem Viriatus multis proeliis fractum fugauit. This brief statement of Orosius shows how he likes to stress disasters for his own purpose (Appian reports only the speedy defeat of C. Plautius, followed by his cowardly inaction).

52 The praenomen Gaius is not attested among the Plautii Hypsaei (who are known to have used only M. and L.), though it is conceivable that he was a (third-born) son of L. 
hus, he withdrew into winter quarters in mid-summer, allowing the Lusitanians to roam freely and extort agricultural produce. This led to the condemnation of the Roman praetor, probably for perduellio, on his return to the city ${ }^{53}$.

The Livian Perioch ${ }^{54}$ states that after Viriathus had defeated the praetors «M. Vetilius» and C. Plautius, "this enemy caused so much fear that a consular commander and army was required against him». This must refer to the dispatch of Q. Fabius Maximus Aemilianus to Hispania Ulterior as consul in $1455^{55}$. The campaigns of Vetilius and C. Plautius obviously preceded Q. Fabius' consulship. But what is their upper date? This Periocha does not help us fix the chronology more exactly ${ }^{56}$. However, the Oxyrhynchus Periocha reports success over the Lusitanians in 147, which may correspond with Appian's statement that Vetilius defeated this people on first arriving in his prouincia ${ }^{57}$. Appian, after narrating Viriathus' first success against Vetilius, states that the Lusitanian commander fought for eight years against the Ro-

Hypsaeus, pr. 189. Another alternative is that he was a solitary descendant of one of the lines of the Plautii who are so prominent in the consular Fasti of the fourth century (the Plautii Proculi and Vennones used this praenomen; note also C. Plautius Decianus, cos. 329). A C. Plautius Numida is said by Valerius Maximus to have been a senatorii uir ordinis who committed suicide at the death of his wife (IV 6,2). He (or a predecessor) could have picked up his cognomen anytime starting with the period of the Second Punic War; his date and his relationship to our praetor do not admit speculation.

${ }^{53} \mathrm{Ib}$. 64,270-272. Diodorus states that upon his return to Rome, C. Plautius was con-

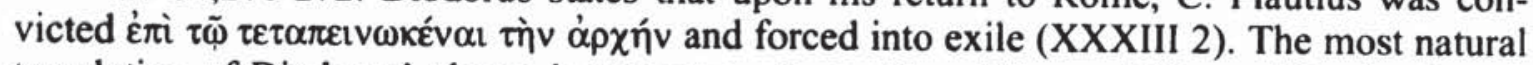
translation of Diodorus' phrase is maiestas minuta (thus Münzer, RE, s.u. Plautius 9, col. 9). That is doubtless what Diodorus (who lived under Caesar and the early years of Augustus' reign) had in mind. But Diodorus is surely being anachronistic in this; in the mid-second century the proper charge would be perduellio (see R. A. Bauman, The Crimen Maiestatis in the Roman Republic and Augustan Principate, Johannesburg 1967, p. 22; E. Gruen, Roman Politics and the Criminal Courts, 149-78 B. C., Cambridge, Mass. 1968, p. 29 with n. 46).

${ }^{54} \mathrm{Per}$. LII.

5s Fabius fought against Viriathus, it is clear from Appian, in his actual consulship: $I b$. 65,273-278; cf. Val. Max., VI 4,2.

56 In Per. LII the defeat of C. Vetilius and the lack of success of C. Plautius is found immediately after the report of fighting in Greece in 147-146, and the triumphs of Q. Caecilius Metellus and P. Cornelius Scipio Aemilianus. These triumphs were celebrated in close proximity to each other (App. Lib. 135,643), and thus both probably in 146, or at the latest, early 145 (Appian in fact gives a date, "around the 160th Olympiad" (= the year 140), which is impossible; for other sources on these triumphs - none with a definite datesee $M R R$ I, p. 467). But events in Spain are being told continuously, in the same manner as the campaigns in Greece just above. The notice in the Periocha, which covers two campaigns, may refer to either 147-146 or 146-145.

57 Oxy. Per. LI (see Note 46); App. Ib. 61,257. Polybius' (XXXVIII 10,10) statement, that in 147 the Achaean leaders Diaeus and Critolaus reckoned that the Romans feared the

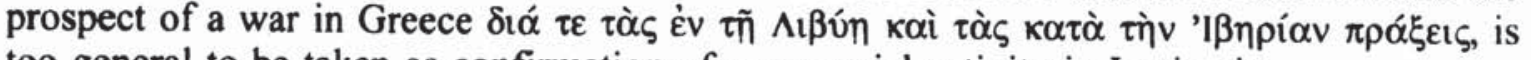
too general to be taken as confirmation of any special activity in Lusitania. 
mans, i.e. until his death in $139^{58}$. This notice seems to place Vetilius in Spain in 147.

In Orosius the defeat of "Vecilius" is included under the events of the year $146^{59}$. One cannot place too much confidence in this account. Orosius tells a continuous story about the war against Viriathus in Spain, attaching it by an obvious synchronism to the «big yean» $146^{60}$. It is impossible to say what precisely in Spain he dated to 146, and whether he took it from Livy. The Periocha, as we have seen, does not exclude 147 as the date of Vetilius' arrival, and Appian positively seems to say so. Orosius' synchronism may be an inadequate counter-argument.

On a «minimalist» interpretation, Vetilius was $p r .147$ and C. Plautius $p r$. 146 in the prouincia of Hispania Ulterior. Q. Fabius Maximus Aemilianus took command as consul 145. So all recent treatments of this period, with the notable exception of J. S. Richardson. Richardson ${ }^{61}$ makes Vetilius praetor in 146 and C. Plautius in 145-the same year and prouincia as the consul Q. Fabius Maximus. His reasons are not cogent: «Livy seems to have placed Vetilius' period in Ulterior in 146, and Orosius, who was probably drawing on the Livian tradition, states that the troubles with Viriathus, of which the first was the defeat of "Vecilius" began in the same year as the sack of Corinth, that is 146». In fact, the Periocha does nothing of the sort, nor does Orosius say the problems with Viriathus "began" in 146. Orosius only places the defeat of Vetilius in 146 (with no indication of date of appointment). Yet Richardson may have a point. If $\mathrm{C}$. Plautius was prosecuted perduellionis and convicted, recall and supersession in his prouincia by a consul is entirely possible. In consequence, the year 145 is not excluded for his praetorship. But it seems Vetilius must have gone to Spain in 147.

Next we have to place two shadowy figures, Claudius Unimanus and C. Nigidius ${ }^{62}$. When taken in combination. Florus, Orosius and the De Viris

58 Ib. 62,264 with $74,313-314$.

59 Oros., V 4,2.

${ }^{60}$ Oros., V 4,1-6 (everything happens isdem consulibus!) with V 3,1.

${ }^{61}$ Hispaniae, pp. 185-187.

62 Claudius Unimanus is found in Orosius (V 4,3 «Vnimammus»), Florus (1 33,16) and the De Viris Illustribus $(71,1$ imperator). Unfortunately, no praenomen is preserved for this commander. It is just possible however that he was a patrician Pulcher (Münzer, RE, s.u. Claudius 376, col. 2885). Münzer points out that Ap. Claudius Caecus (cos. 307, II 296) had the nickname "Centemmanus" (Pompon., Dig. I 2,2,36); "Unimanus" may have been a tag attached to this praetor on the analogy of the famous censor (and ancestor?). Or Claudius Unimanus may in fact have lost an arm. The physically impaired were not excluded from the praetorship: M. Sergius Silus, pr. urb. 197, was similarly handicapped (Plin., $\mathrm{NH}$ VII 104-105). But exact identification is obviously impossible. C. Nigidius receives a mention only in De Viris Illustribus 71,1 . No title is given for the man, and, as we shall 
Illustribus provide a rough order of events for the actions of these men. After C. Plautius was worsted in the field, the Romans sent Claudius Unimanus against Viriathus with a large force; the now-predictable disaster ensued, with a loss of the standards and fasces. Viriathus next defeated C. Nigidius ${ }^{63}$.

Appian's silence on Claudius Unimanus (and, to a lesser extent, Nigidius) is strange, but it may be explained by his arrangement of the history of the Spanish wars by geographical areas of fighting ${ }^{64}$. If Claudius was a praetor, he is unlikely to have held Hispania Ulterior ${ }^{65}$. There is in fact some indirect evidence on his prouincia. Citing Claudius Quadrigarius, Orosius reports that at the same time as the defeat of Claudius Unimanus a Roman force of 1,000 men skirmished in a glade with a much smaller Lusitanian force; the Roman losses, though not great, were disproportionate to the enemy's. An anecdote about a particularly daring Lusitanian infantryman follows ${ }^{66}$. This should refer to an incident outside of

see, there is no compelling reason to believe that he was a praetor. We know of no other Nigidii - magistrates or otherwise- until P. Nigidius Figulus, pr. 58 and eminent Pythagorean. An Etruscan origin for the family is likely, though we can only guess how the Nigidii were enfranchised (see $C I L \mathrm{I}^{2} 2640=I L L R P$ 814, from Perusia, with W. V. Harris, Rome in Etruria and Umbria, Oxford 1971, pp. $321 \mathrm{f}$ (cf. pp. 200-201); also E. Badian, Klio 71,1989 , pp. 585 and 591-593). The Roman political system had already started to open up a bit to some Etruscan families. Note M. Perperna (father of the cos. 130), legate in 168 (the head of an embassy-MRR I, p. 430), and thus a senator.

${ }^{63}$ Oros., V 4,3-4, explicitly placing Claudius' defeat after that of C. Plautius; Florus, I 33,15; and also De Vir. Ill. 71,1, Viriathus... bellum aduersum Romanos sumpsit eorumque imperatorem Claudium Vnimanum, dein C. Nigidium oppressit. This source then skips to the end of Viriathus' career, his negotiations with M. Popillius Laenas, cos. 139, and his death at the hands of assassins sent by Q. Servilius Caepio, pro cos. in that same year $(71,2-4)$.

64 At $\mathrm{Ib} .63,265$ - in his account of the events of the year 147 in Ulterior- Appian

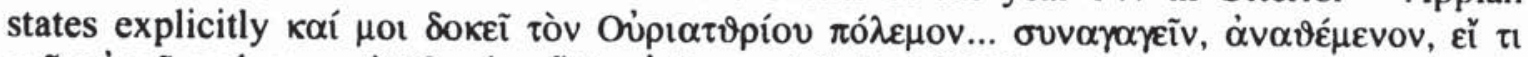

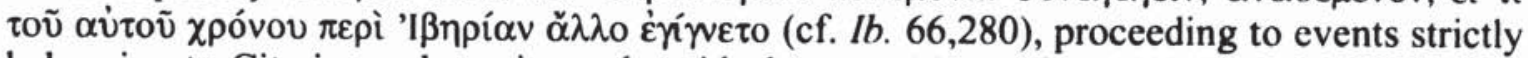
belonging to Citerior and starting only with the year 143 at $I b .76,322$.

65 Florus (I 33,16-17) makes Claudius Unimanus a predecessor of two consular commanders in the war against Viriathus: (Q.) Fabius Maximus (Servilianus) (cos. in Hispania Ulterior in 142 and pro cos. 141-140) and his "successor" (M.) Popillius (cos. in Hispania Citerior in 139, pro cos. 138). The fasti for Hispania Ulterior are full for the years 147 or 146 through 144: C. Vetilius, C. Plautius, and Q. Fabius Maximus Aemilianus (cos. 145 and pro cos. 144). In 143 we have notice of a "Quintius» operating in Ulterior, who will be discussed below; in 142 the consul Q. Fabius Maximus Servilianus received Ulterior. From 142 through 133 Hispania Ulterior was held by consular commanders. There is no room for additional commanders in this prouincia unless either Claudius Unimanus or C. Nigidius was sent as a praetor to serve as adiutor to Q. Fabius Maximus Aemilianus, cos. 145. But this practice is not attested in this period, and it is unlikely that the Senate could have spared a praetor to serve in this capacity when there were now (after 146) eight praetorian prouinciae but only six praetors. For this development, see E. Badian, Gnomon 51, 1979, pp. 792-794; T. C. Brennan, Chiron 22, 1992, pp. 137-144.

66 Oros., V 4,5-6 = Claudius Quadrigarius fr. 69 in H. Peter, Historicorum Romanorum Reliquiae $\mathrm{I}^{2}\left[=H R R^{2}\right]$, Leipzig 1914, p. 231. 
Claudius' prouincia, i.e. in Ulterior. On a reasonable interpretation, it would seem that Claudius Unimanus was praetor (or even a promagistrate) in Citerior.

C. Nigidius however may not even have to be squeezed into the fasti of commanders for the Spains. Though it would be rash to press the language of such a late and condensed source as the De Viris Illustribus, the passage in question refers to an imperator in the singular, Claudius Unimanus. C. Nigidius need not be a successor to Claudius Unimanus in his prouincia, but rather, a subordinate of the consul Q. Fabius Maximus Aemilianus in Hispania Ulterior ${ }^{67}$. Long ago, E. Kornemann ${ }^{68}$ conjectured that this man was the $0 \pi 0 \sigma-$

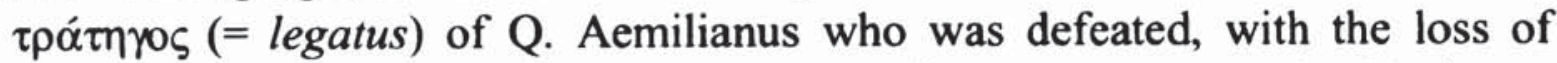
much booty, after the consul's arrival in $145^{69}$. As Appian tells it, this íroo$\tau \rho \alpha \dot{\tau} \eta \gamma \circ \varsigma$ led out a force after Viriathus fell on and killed a number of Roman wood cutters-an attack just possibly to be equated with the skirmish in the glade between 1,000 Romans and 300 Lusitanians which Claudius Quadrigarius saw fit to report. Kornemann's identification is an entirely satisfactory solution to the problem of C. Nigidius. He would still be a senator, probably an ancestor of P. Nigidius Figulus. But only Claudius Unimanus need be placed in the fasti of Roman commanders, as praetor or a prorogued praetor in Hispania Citerior in (surely) 145.

We know of one other commander in Spain during this period, C. Laelius $p r{ }^{70}$. Laelius' praetorship had two high points which have come down to us. The first was the speech he delivered to defeat the lex de sacerdotiis of the $t r$. pl. C. Licinius Crassus ${ }^{71}$. The other was his successful military action against Viriathus, praised by Cicero in the De Officiis in a passage which comes very near to an elogium ${ }^{72}$. Cicero does not speak of an outright victory over Vi-

${ }^{67}$ Occasionally sub-praetorians who served in Spain in this period are named in our sources: the quaestor Terentius Varro (Ib. 56,234-the year 154); the tr. mil. Q. Occius (Val. Max., III 2,21); the tr. mil. C. Fannius M.f. (Ib. 67,287-142); and Memmius, P. Rutilius Rufus, Sempronius Asellio, all tribuni militum under P. Cornelius Scipio Aemilianus at Numantia in 134 (MRR I, p. 491). It is no surprise of course to find mention of the Spanish service of such famous men as P. Scipio Aemilianus (tr. mil. under L. Licinius Lucullus in 151-MRR I, pp. 455-456) and Ti. Sempronius Gracchus (quaestor under C. Hostilius Mancinus in 137-MRR I, p. 485).

${ }_{68}^{6}$ Die neue Livius-Epitome aus Oxyrhynchus. Klio Beiheft 2, Leipzig 1904, p. 99, cf. 102.

${ }^{69} \mathrm{Ib} .65,275-276$.

70 The date is certain from Cic. De Amicitia 96.

71 E. Malcovati, Oratorum Romanorum Fragmenta Liberae Rei Publicae ${ }^{4}$, Turin 1976, I 117-118, to which add Cic. De Amicitia 96.

72 Cic., De Off. II 40... Viriatus Lusitanus, cui quidem etiam exercitus nostri imperatoresque cesserunt, quem C. Laelius, is qui Sapiens usurpatur, praetor fregit et comminuit ferocitatemque eius ita repressit, ut facile bellum reliquis traderet; also see Brut. 84 bellica laude... in qua ipsa egregium Viriathi bello reperimus fuisse Laelium. 
riathus, only the fact that Laelius broke the Lusitanian leader's spirit. Yet C. Laelius may well have been the man who routed Viriathus before Fabius Aemilianus' success as pro cos. in 144, whom Appian calls the "second» man to have defeated the Lusitanian leader.

How can we fit C. Laelius into the Spanish fasti? Cicero states that C. Laelius left "an easy war for the others». He is surely exaggerating. Nevertheless, his statement would be positively absurd unless the command of Claudius Unimanus preceded that of C. Laelius-that much seems certain. We have seen that the fasti for Ulterior in the years following 146 are full. Matters are also tight, so to speak, in Citerior, since in 143 the prouincia was declared consular and allotted to Q. Caecilius Metellus Macedonicus.

If C. Laelius delivered his speech de sacerdotiis early in his praetorship and then let for his prouincia, his success against Viriathus can then be dated to 145 or even 144 (if he were prorogued, at least until the arrival of a successor). Broughton and Knapp make Claudius Unimanus pr. 146, C. Nigidius pr. 145, and C. Laelius pro pr. 144 in Hispania Citerior, without explaining exactly how C. Laelius ended up in that prouincia ${ }^{73}$. On the other hand, Simon ${ }^{74}$ suggests that the unsuccessful Claudius Unimanus, whom he makes pr. 145, was replaced in mid-year by C. Laelius; and Laelius in turn was succeeded by C. Nigidius as pr. 144. J. S. Richardson admits Simon's hypothesis as one possibility: «it is likely that there was a defeat of some kind in Citerior in 144, since the sending of the consul Q. Metellus Macedonicus (cos. 143) would be more justified if it came after a disaster such as that attributed to Nigidius, rather than after the victory of Laelius, even though this may have been exaggerated by Cicero». Richardson continues: «if Nigidius is excluded as a commander with imperium in Citerior, it would still be possible to place Unimanus' tenure after that of Laelius, so that the sending of Metellus resulted from his defeat»" ${ }^{75}$.

The arguments of Simon and Richardon are far from satisfactory. These scholars are too fond of postulating a pattern of repeated recalls to make sense of the Spanish fasti for this period. Richardson adduces as a parallel for the «recall» of Claudius Unimanus in 145 the presumed replacement of C. Plautius in that same year by the consul Q. Fabius Aemilianus-which is not at all certain. Against Richardson, we also may note that C. Plautius was prosecuted, while Claudius Unimanus (as far as we know) was not. A serious case of perduellio which

\footnotetext{
${ }^{73}$ Broughton, MRR I, p. 469, with III, p. 116; Knapp, Roman Experience, p. 196; cf. Richardson, Hispaniae, p. 188.

${ }^{74}$ Roms Kriege, p. 78.

75 The emphases are Richardson's; both quotations are from Richardson, Hispaniae, pp. 188-189.
} 
resulted in the exile of a Roman praetor is a much different thing from the defeat of Claudius, as reported in our sources ${ }^{76}$. In addition, after 146 , when the number of praetorian prouinciae had outstripped the number of praetors elected for each year, there were not enough praetors to replace unsuccessful commanders in distant prouinciae in the course of their year of office ${ }^{77}$.

Furthermore, Richardson cannot be right in his (tentative) suggestion that Claudius Unimanus' command came in 144, after that of Laelius, and his defeat prompted the sending of the $\cos$. Q. Metellus Macedonicus. For a start, Appian relates that in 144 Viriathus stirred up the Aravaci (and their city Numantia), Belli and Titti to revolt after his defeat at the hands of pro cos. Fabius Aemilianus - sufficient cause to declare Citerior consular for the next year ${ }^{78}$.

There is also good reason to think that in $144 \mathrm{C}$. Laelius ( $p r .145)$ had gone to Citerior to hold a command only ex praetura, from a city jurisdiction. Valerius Maximus provides the background to this administrative decision ${ }^{79}$. Valerius describes what must be the actual debate in the Senate on the consular prouinciae for 144 (i.e. in the very beginning of the year). Both the new consuls, Ser. Sulpicius Galba and L. Aurelius Cotta, were eager to receive one of the Spains and the war against Viriathus as a prouincia (perhaps extra sortem). There was great division in the Senate on the issue of which consul should be sent: Ser. Galba and L. Cotta each must have had supporters. P. Cornelius Scipio Aemilianus was asked for his sententia in this debate, «with all in suspense which way his opinion would lean». When Aemilianus advised that neither Galba nor Cotta be sent, his opinion surprisingly won the day.

76 If Unimanus is indeed a Claudius Pulcher, as Münzer suggested, we ought to know if he was prosecuted. However, if he was an obscure plebeian Claudius - rather unlikelywe might not. The case of C. Hostilius Mancinus, cos. 137, will hardly do as a parallel, as Richardson would have it. It is true that Mancinus was replaced in Citerior by his consular colleague M. Aemilius Lepidus Porcina in mid-137, and Porcina was relieved of his command as pro cos. in 136 (MRR I, p. 484; p. 486). Nevertheless, Mancinus was guilty of a shameful surrender as well as engineering a disgraceful treaty. Porcina had attacked the Vaccaei over the express prohibition of the Senate, which had been relayed by two legati (Ib. 81,351); he was due to be superseded anyway (by the cos. $136 \mathrm{~L}$. Furius Philus - see Ib. 83,358-359 with Val. Max, III 7,5). C. Plautius, C. Hostilius Mancinus and M. Aemilius Lepidus Porcina are extreme cases, and tell us nothing about normal Roman policy in the 140s.

77 The shortage of praetors at this time (see Note 65 above) may possibly be seen in the case of Q. Marcius Rex, who was pr. urb. in 144, and prorogued into 143 to complete his activities relating to the water supply of Rome (Front. Aq. I 7). A secure example of prorogation of an urban praetor into a second year of office last appears in our record in the very early years of the second century, when there were only four praetors $(C$. Sergius Plautus, pr. urb. 200 and pro pr. 199; and L. Quinctius Flamininus, pr. urb. 199 and pro pr. (probably) 198-194).

${ }_{78}$ App. Ib. 66,279-280; 76,322.

79 Val. Max., VI 4,2. 
Consular prouinciae were decided and drawn (or arranged) before praetorian. Up to the time of Aemilianus' sententia, there must have been a general expectation that Citerior would be declared consular. The adoption of Aemilianus' sententia in the Senate debate meant that a praetor had to be sent to Citerior. It would not be all that easy, however, to make one available. With the addition of Macedonia and Africa as praetorian prouinciae in 146, there were now simply not enough praetors for Rome to meet her administrative commitments. These circumstances, I would suggest, led to the special appointment of the city praetor C. Laelius for 144 and his dispatch to Hispania Citerior, only to be relieved the next year by the consul Q. Metellus. One might add that Scipio's sententia may not have been entirely disinterested. At this point - a year after his Punic triumph - his auctoritas must have been exceptionally powerful. Kornemann ${ }^{80}$ rightly notes that Scipio would want to have his brother Q. Fabius Maximus Aemilianus prorogued in Ulterior. Münzer went a step further, suggesting that Scipio wanted his friend Laelius (who Münzer makes a $p r$. for Spain in 145) prorogued in Citerior ${ }^{81}$. Yet neither scholar saw that Scipio may have secured an appointment extra ordinem in Citerior for his friend. It really is too much of a coincidence that Laelius shows up in Spain exactly around this time.

It is interesting that C. Laelius, who, as pr. 145, was technically eligible to run for the consulship of 142 , only put in his professio for the elections for 141. Had Laelius indeed served in Spain ex praetura in 144, his decision becomes understandable. Once superseded by the consul Q. Metellus Macedonicus in 143, Laelius would not have all that much time to get back to Rome and conduct an adequate campaign for 142, especially when L. Caecilius Metellus Calvus was in the running - a relative, perhaps the brother of the consul ${ }^{82}$. A candidacy in 142 (for 141) made better sense for Laelius: in that year there was an excellent chance his friend Scipio Aemilianus would be censor, adding even more auctoritas to his support ${ }^{83}$. In the event, the talented nouus homo (and fellow protégé of Scipio) Q. Pompeius won election for 141, delaying C. Laelius' consulship until the next year ${ }^{84}$.

${ }^{80}$ Die neue Livius-Epitome, p. 99.

81 Römische Adelsparteien und Adelsfamilien, Munich 1920, p. 247 with RE, s.u. Laelius 3, col. 406.

82 Vell. Pat., II 8,2 thought that Q. Metellus Macedonicus and L. Calvus (elected cos. 142) were brothers; at present there is no evidence which contradicts this assertion (Badian, Chiron 20, 1990, pp. 400-401).

${ }^{83}$ In the event, Scipio was elected censor for 142, though not without competition for the patrician place from Ap. Claudius Pulcher, cos. 143 (Plut. Aem. 38,3-4; Mor. 200 D = Apoth. Scip. Min. 9; Cic. Scaur. 32).

${ }^{84}$ Plut., Apoth. Scip. Min. $8=$ Mor. 200C; cf. Cic., Tusc. V 54, which speaks of C. Laelius' (single) repulsa, confirming that 142 was the first year in which he sought election 
Though absolute certainty is impossible, the most natural interpretation of the (admittedly flimsy) evidence makes Claudius Unimanus praetor in Hispania Citerior in 145, and C. Nigidius a subordinate of the consul Q. Fabius Maximus Aemilianus in Ulterior, who lost a battle to Viriathus in that same year. C. Laelius, pr. 145 was then sent to command in Citerior ex praetura for 144, probably the first instance of such an appointment for Spain ${ }^{85}$. C. Laelius' success against Viriathus was of course welcome, yet counted for nought in the Roman administrative policy. It had been planned that Citerior be declared consular for 144, and the sending in 143 of Q. Metellus Macedonicus as a consular successor for Laelius (who had served only as a stopgap) was merely the implementation of that decision-one year later than had been expected. This was all just as well. The military situation in Citerior had grown more grim with the outright defection of the Celtiberian Aravaci and Numantines. Once in Citerior, Macedonicus seems to have met Viriathus in battle, and come off the worse for it ${ }^{86}$.

\section{The Roman Commander in Hispania Ulterior in 143}

We have seen that Q. Fabius Maximus Aemilianus, cos. 145, was sent to Ulterior and prorogued into 144. Appian's text does not allow us to tell exactly who it was that succeeded Fabius in this prouincia in 143. Following the report that Fabius (in his second year) proceeded to winter quarters at Cordoba,

for the consulship. For Pompeius' skill as a campaigner, see P. Rutilius Rufus $H R R^{2}$ fr. 7 Pompeius elaborauit, uti populum Romanum nosset eumque artificiose salutaret. Cicero thought highly of him, both as an orator (Brut. 96 non contemptus orator temporibus illis), and as a person (de Rep. III 28 and Mur. 16). A breach between Pompeius and Scipio Aemilianus followed Laelius' repulsa: Cic., De Amic. 77 (Laelius speaking) ab amicitia $Q$. Pompei meo nomine se remouerat, ut scitis, Scipio, with E. Gruen, Roman Politics and the Criminal Courts, 149-78 B. C., Cambridge, Mass. 1968, p. 34, n. 59, for various theories regarding the permanence of this split.

${ }_{85}$ The first generally accepted instance of a city praetor setting out for an overseas province ex praetura is C. Marius, pr. 115 and pro cos. in Hispania Ulterior in 114 (and possibly 113). See $M R R$ I, pp. 532, 534 and 535, n. 3; III, p. 140, and T. C. Brennan, Chiron 22,1992 , p. 103, n. 2. Of course, this practice soon grew common (Brennan, loc. cit.), and was finally institutionalized for all praetors by the dictator L. Cornelius Sulla in his reforms of 81 .

${ }^{86}$ [M]etellus cos. a Lusitanis uex[atus est] (Oxy. Per. LIII-the year 142). A. E. Astin in Historia 13, 1964, pp. 247-254, effectively demolished the long-standing hypothesis (most recently accepted by Simon, Roms Kriege, pp. 70 and $80 \mathrm{ff}$.) that L. Caecilius Metellus Calvus, cos. 142, is the Metellus referred to in the Oxy. Per. There is no identifying agnomen-and no other evidence for a Spanish command. Astin must be correct in his view that the passage refers to Q. Metellus Macedonicus (who was certainly in Citerior - p. 248, n. 16) and that the title cos. technically should be pro cos. (though no emendation should be made). 
Appian sketches the activities of a "Quintus» or "Quintius» against Viriathus in Ulterior, a different man from the cos. $145^{87}$. After some initial success, this "Quintius» lost 1,000 men as well as his standards in an encounter with Viriathus. When Viriathus afterwards drove out the Roman garrison from Ituc$\mathrm{ca}^{88}$ and ravaged the land of the Bastetani, the cowardly and inexperienced "Quintius» did not come to their aid. Instead this commander withdrew to Corduba in mid-autumn to winter quarters, and sent a native Spaniard or (more probably) Hispaniensis, C. Marcius of Italica, against the Lusitanian. In the following year the brother of Aemilianus (Q.) Fabius Maximus Servilianus ${ }^{89}$ (cos. 142), arrived as the successor of "Quintius». His first task was the relief of Itucca ${ }^{90}$. Starting with Servilianus' appointment, down through 133 both Spanish prouinciae are invariably entrusted to consuls or ex-consuls ${ }^{91}$.

Who is this "Quintius»? This should be a Roman nomen; Appian is generally very careful with Roman names in the Iberica, as policy never using praenomen alone to identify a person he has not yet mentioned ${ }^{92}$. But more than two centuries ago J. Schweighäuser, in his 1785 edition of Appian, suggested that a copyist's error has obscured this man's true identity. By a textual transposition, this early editor identified the "Quintius» of Appian with Q. Pompeius A.f., the future cos. 141, who would soon serve in Hispania Citerior. This idea recently has received (guarded) endorsement from J. S. Richardson. But Schweighäuser's transposition will not stand scrutiny ${ }^{93}$.

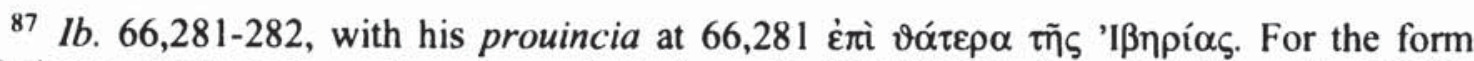
"Quintus" (only once, and surely a mistake) see $I b .67,283$ init.; for "Quintius", Ib. 66,281; 282 bis. The name has naturally often been emended to "Quinctius»; "Quintius" is a common spelling for that nomen in texts. Astin (Historia 13, 1964, pp. 251-252) amply refutes Münzer's suggestion (obiter in RE, s.u. Fabius 115, col. 1813) that this man is L. Caecilius Metellus Calvus (cos. 142). Münzer himself apparently abandoned this idea, since later (Römische Adelsparteien, p. 121, n. 1) he suggests he may belong to the Quinctii Crispini. The Quinctii Flaminini are also a possibility (son of the pr. 177).

${ }^{88}$ Perhaps to be identified with modern Martos: see H. J. M. Roldán, Itineraria Hispana, Valladolid 1975, p. 273 s.u. Tucci.

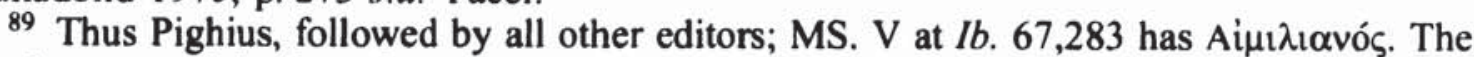
need to emend is clear from the mention of Servilianus at $I b .67,287 ; 68,288$ and 290 ; 69,293 and 70,296 .

${ }_{90} \mathrm{Ib} .67,283-284$.

91 Richardson (Hispaniae, p. 131, with n. 26) tentatively makes Appian's «Quintius» pr. 143 and commander in Hispania Ulterior in 143 and (oddly) 142, postulating that Servilianus only arrived to relieve this man as pro cos., i.e. in 141. This chronology cannot be right. Appian's account implies that the command of "Quintius" is less than one season long (though that does not necessarily count for much!). More importantly, there is no indication in any of our sources that Servilianus arrived unusually late; in fact, Astin (Historia 13, 1964, pp. 249-250) has demonstrated that Servilianus was in Ulterior as consul in 142.

92 See Appian, Prooem. 13,51-52 with Simon, Roms Kriege, pp. 83-84.

93 See Appendix B. 
Another difficulty with Schweighäuser's identification is that, under the terms of the lex Villia Annalis (which specified a biennium between praetorship and consulship), Q. Pompeius cannot have been praetor in 143 and then consul in $141^{94}$. If he arrived in Ulterior in 143, it must be that he was pr. 144 in the prouincia peregrina (the urban praetor is known), obtaining Spain only ex praetura. We have a plausible motive for the prorogation of the $\mathrm{pr} .145 \mathrm{C}$. Laelius: the unexpected removal of the Spains from the consular sortition for 144, coupled with Scipio's intervention on behalf of his best friend. It is quite difficult to see why Q. Pompeius, if a city praetor in 144 , would be dispatched to Ulterior. In 143 it was desirable that two new commanders be sent to the Spains. Q. Fabius Maximus Aemilianus (cos. 145) had been in the prouincia of Hispania Ulterior for two years; I have suggested C. Laelius (pr. 145) had been sent to Citerior in unusual conditions to serve only as a stopgap. The incoming consuls $-\mathrm{Q}$. Caecilius Metellus Macedonicus and Ap. Claudius Pulcher, men of much greater potentia than their immediate predecessors- would not stand for another postponement. At least one of the Spanish prouinciae now had to be declared consular. The consuls for 143 may have revived the competition of the previous year to obtain the command against Viriathus - especially if the successes of Q. Fabius Maximus Aemilianus and C. Laelius in 144 had raised hopes that Viriathus could soon be beaten. Indeed, Dio reports the resentment that Ap. Claudius Pulcher felt toward Metellus after he had the misfortune to draw Italy as his prouincia ${ }^{95}$. Since there was no war at hand in «Italia». Ap. Pulcher is said to have tried to turn a dispute between the gold-rich Salassi and their neighbors into a pretext for a military campaign ${ }^{96}$.

We can understand why C. Laelius would be replaced by the consul Q. Caecilius Metellus Macedonicus. The declaration of Citerior as a consular prouincia was one year overdue. But if Hispania Ulterior was to be declared praetorian, why not send a praetor in his year of office? The disparity in the number of praetorian prouinciae and praetors after 146 was not so severe that two city praetors in a row had to go to Spain ex praetura to fight the war with Viriathus, which was now dragging into its fourth year. Furthermore, there was no other important war being waged elsewhere, as far as we know ${ }^{97}$.

94 Thus rightly G. de Sanctis, Storia IV 3, p. 226, n. 168, who points out that Q. Pompeius can only have gone to Spain in 143 as a prorogued praetor. Richardson (Hispaniae, pp. 189-191), though he admits Q. Pompeius as a possibility for this command, does not grapple with this difficulty.

95 Dio, fr. 74,1.

${ }^{96}$ There is no doubt that Claudius was particularly hungry for a triumph (cf. Val. Max., V 4,6), which he eventually forced through without obtaining the permission of Senate or People, and over tribunician opposition (MRR I, p. 471).

97 Though there was (or soon would be) trouble in Macedonia at this time (Varro, $R R$ II 4,1-2; Per. LIII), which might necessitate the sending of a new praetorian commander. 
Sumner ${ }^{98}$ found the career of Q. Pompeius as Broughton (initially) reconstructed it too much to believe: «praetor by 144 (date established from the lex Villia Annalis), he was, as promagistrate in 143, defeated by Viriathus in Farther Spain. There he remained in 142 until succeeded by the consul Fabius Servilianus, whereupon he returned to Rome and was brilliantly elected consul for 141 !». Sumner is right: Appian's "Quintius» cannot have made it to the consulship for 141. If Q. Pompeius was in Ulterior in 143, and relieved only some way into 142 by the consul Q. Fabius Maximus Servilianus, he will not have had very much time to canvass before the elections ${ }^{99}$. C. Laelius was nobilis (as son of the consul of 190) ${ }^{100}$, had distinguished himself fighting in Spain, and enjoyed the full backing of a most influential ex-consul who was currently censor. Q. Pompeius's nouitas ${ }^{101}$ did not allow him to be dilatory in the matter of canvassing; if he wanted to be consul, he had to start at the first available opportunity. It is hard to accept the idea of Pompeius arriving from Spain someway into 142, and then making a last-minute decision to run for office, thereby confounding his political associates. Q. Pompeius must be excluded as the Roman commander in Ulterior in 143. We are left with a perfectly plausible alternative: a Quinctius (Crispinus or Flamininus) as a praetor in 143.

\section{T. Corey Brennan}

98 Orators, p. 48.

99 Q. Pompeius was in Rome when C. Laelius was in the first stages of his canvass, surely early 142: see Plut., Mor. $200 \mathrm{C}$ with Astin, Scipio Aemilianus, pp. $122 \mathrm{f}, 257$ (incorrectly dated to 141$), 311 \mathrm{f}$.

100 Cic., Phil. XI 17.

101 See Cic., Verr. II 5,181. 
APPENDIX A

SUGGESTED FASTI OF THE ROMAN COMMANDERS IN SPAIN,

157-150 AND 147-140

N.B.: All the praetorian commanders presumably will have held consular imperium.

HisPania Citerior

157

156

155

154

153 Q. Fulvius Nobilior cos.

$152 \mathrm{M}$. Claudius Marcellus cos.

151 L. Licinius Lucullus cos.

150 L. Licinius Lucullus pro cos.

147

146

145 Claudius Vnimanus $p r$.

144 C. Laelius ex praetura

143 Q. Caecilius Metellus Macedonicus cos.

142 Q. Caecilius Metellus Macedonicus pro cos.

141 Q. Pompeius cos.

140 Q. Pompeius pro cos.
HisPANIA VLTERIOR

M.' Manilius $\mathrm{pr}$. (?or prorogued pr.)

L. Calpurnius Piso Caesoninus $p r$.

L. Mummius $p r$.

L. Mummius (prorogued)

M. Atilius (Serranus) $p r$.

M. Atilius (Serranus) (prorogued)

Ser. Sulpicius Galba $p r$.

Ser. Sulpicius Galba (prorogued)

C. Vetilius $p r$.

C. Plautius $p r$.

Q. Fabius Maximus Aemilianus cos.

(with legatus $\mathrm{C}$. Nigidius)

Q. Fabius Maximus Aemilianus pro cos.

Quinctius (Crispinus or Flamininus) $p r$.

Q. Fabius Maximus Servilianus cos.

Q. Fabius Maximus Servilian. pro cos.

Q. Seruilius Caepio cos.

\section{APPENDIX B}

THE TEXT OF APPIAN'S IBERICA AND THE ROMAN COMMANDER IN HISPANIA ULTERIOR IN 143

Slightly below Appian's report of the misadventures of "Quintius» in Hispania Ulterior ( $I b .66,281-282$, the year 143), there is a problematic passage

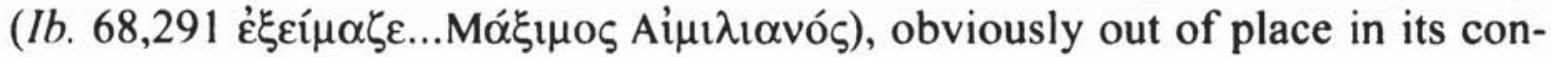
text (the events of the consul Q. Fabius Maximus Servilianus' command in 
Ulterior in 142), which mentions a "Quintus Pompeius son of Aulus succeeding to the command" of a "Servilianus» who had spent two years in his prouincia. This intrusive passage is simply bracketed in the Viereck-Roos edition. However, Schweighäuser (Appiani Historiae Romanae III, p. 282) emended «Servilianus» to "Aemilianus» (i.e. Q. Fabius Maximus Aemilianus, the cos. 145 and pro cos. 144), and then transposed (most of) the intrusive passage to the beginning of Appian's narrative of events in Ulterior in 143. Schweighäuser's transposition makes $I b$. 65,278 (Fabius Aemilianus' second

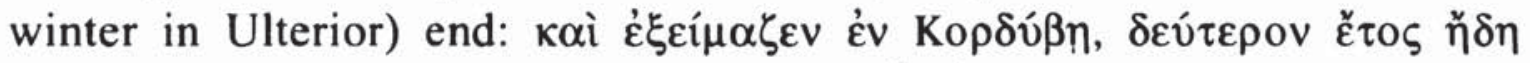

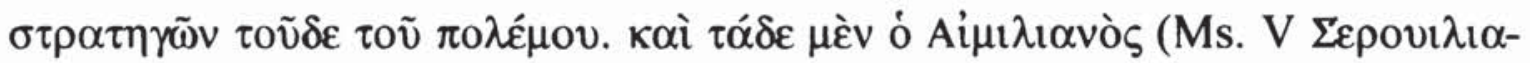

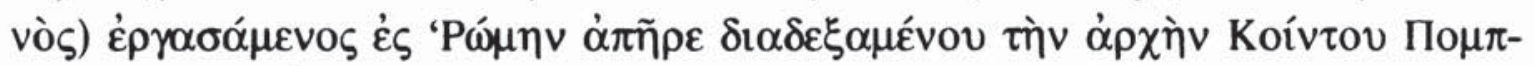

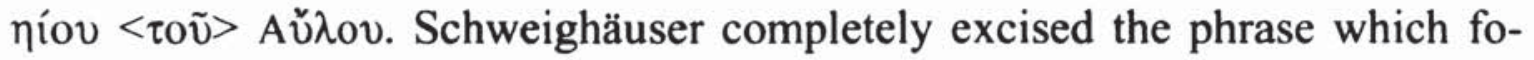

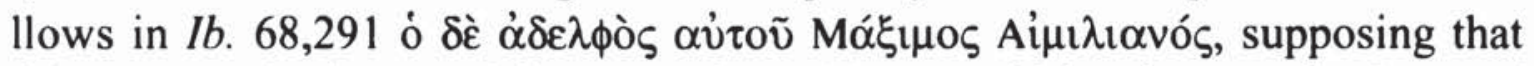
this was a mistaken reminiscence of 67,283 init. which a later scribe inserted to make sense of the now - confused narrative. This same scribe, it was sug-

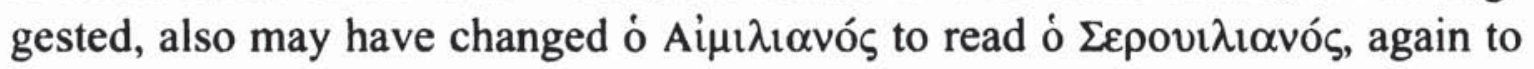
lend sense to the displaced passage (the same mistake - in the other direction - had been made at $I b .67,283$, on which see Note 89). The end result of Schweighäuser's transposition is that Q. Pompeius A.f. (the future consul of 141 ) is made to succeed Q. Fabius Aemilianus in Ulterior in 143, and Pompeius himself is succeeded by Q. Servilianus, the consul of 142 .

Schweighäuser's transposition is very forced, from the technical point of view-as my account of it should make clear. One major difficulty with the transposition of part of $I b .68,291$ to 65,278 is that the reference immediately

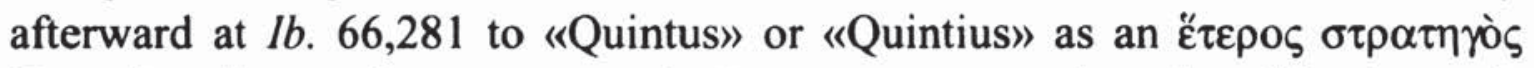
'P $\omega \mu \alpha i \omega v$ then makes no sense (unless we suppose that also this phrase is

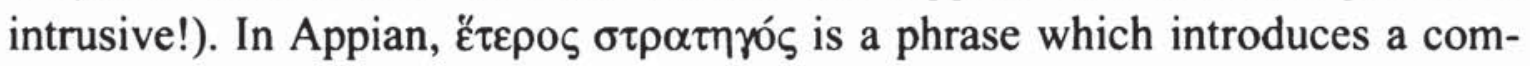
mander who has not been mentioned previously, or reintroduces a commander

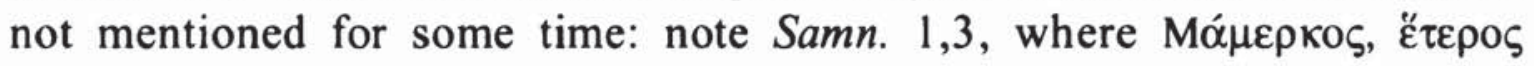

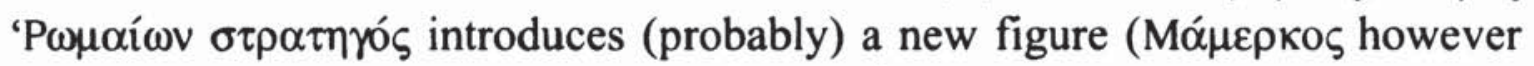
is a mistake for Mópкเоৎ = C. Marcius Rutilus, cos. IV 342); see also Mith.

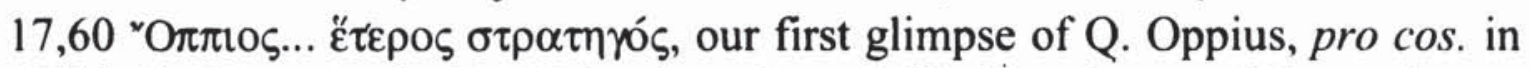
Cilicia in 88. At Mith. 34,133 it reintroduces Mithridates' general Neoptolemus (last found by name at 19,72); cf. perhaps Lib. 63,279 (a speech, alluding to C. Atilius Regulus, cos. 257 , not mentioned since 4,14 ). The phrase is never found at such a close interval to a previously named commander as Schweighäuser's transposition would make it. Schweighäuser's transposition of the «intrusive» passage in $I b .68,291$ is best rejected.

Schweighäuser's proposal has in fact received little support from recent scholars, who generally posit an otherwise unknown «Quinctius» in Ulterior 
in 143. See Astin, Historia 13, 1964, p. 246 n. 4 for a roster of authorities against Schweighäuser's proposal, to which can be added Astin himself; Broughton (MRR, III, p. 160) now states that his earlier notices regarding the promagistracy of Q. Pompeius in 143 and 142 (MRR I pp. 473, 476) should be deleted; cf. also Knapp, Roman Experience, pp. 31, 196, 201-203; and Sumner, Orators, p. 48. A notable exception (long ago) is A. Schulten (NJ 39-40, 1917, p. 222 with n. 2; also Fontes Hispaniae Antiquae, IV, p. 116), who believes that Q. Pompeius A.f. held command in Citerior in 143, while "Quinctius» was the praetor in Ulterior (on this see Richardson, Hispaniae, p. 190, n. 36). That view should be firmly rejected, since Q. Caecilius Metellus Macedonicus can be shown to be in Citerior as cos. 143 (see Note 86).

However, J. S. Richardson (Hispaniae, pp. 189-190) has recently come to the defence of Schweighäuser. He adduces two pieces of evidence which are meant to identify Q. Pompeius A.f. as commander in Ulterior before his consulship of 141, in which he received the prouincia of Citerior. The first is provided by two translators of the Iberica, the Italian translation (probably) by Paolo Manuzio (Venice 1545, «revised and corrected» edition 1551) and the Latin translation of Caelius Secundus Curio (Basel 1554). Both these translators are supposed to have used a Greek copy other than the Vatican codex (see H. White, The Roman History of Appian of Alexandria, I, New York 1899, p. xxxiii with nn. 1 and 2), and each of their translations provides the name

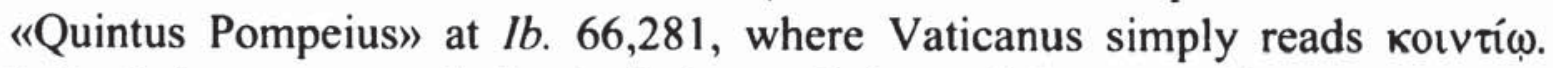
Indeed, they are very similar in their translations of $I b .65,273 \mathrm{ff}$, both reporting e.g. "Quintus Pompeius» for 66,281, «Utica» for Itucca at 66,282, 67,284, etc., and «Martius» for C. Marcius at 66,282 . But these latter two examples are both obvious variants, and quite inconclusive. And «Quintus Pompeius» may

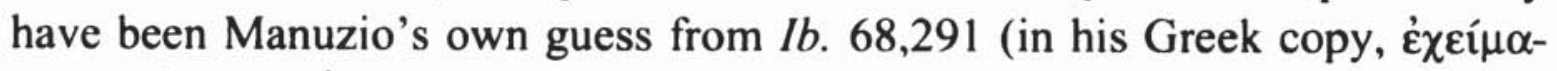

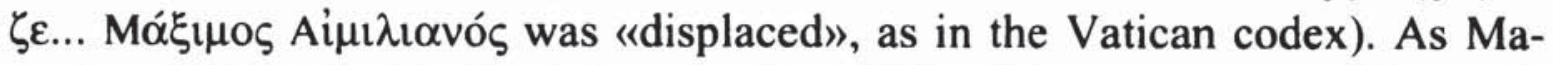
nuzio admitted in his Prefazione to the 1551 edition: «... non parliamo de l'ortographia racconcia, de i punti mutamenti e molti nomi Romani, ed esterni co'l testimonio delle antiche historie corretti». For what it is worth, Schweighäuser (I, p. 282) refused to believe that Curio found the name «Quintus Pompeius» in his text. Curio simply may have got it from Manuzio. The evidence of these translations is interesting, but in no way compelling.

Richardson's second argument for Q. Pompeius A.f. as a (praetorian) commander in Ulterior relies on his interpretation of a fragment by the historian Charax of Pergamum (F. Jacoby, Die Fragmente der griechischen Historiker,

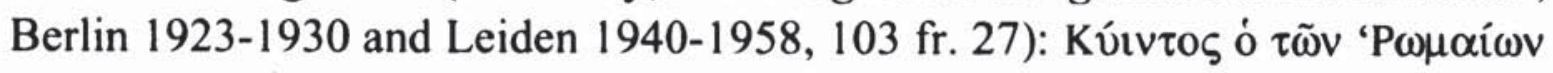

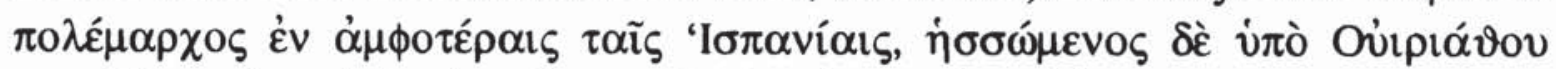

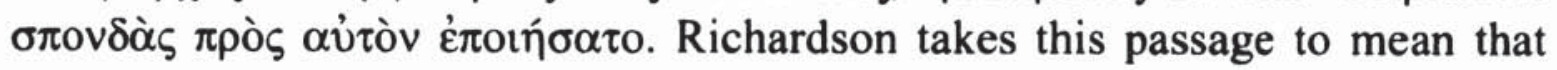


"“Quintus", the general of the Romans, was defeated by Viriathus in both the Spains and made a treaty with him", in other words, a "confused reminiscence of both Pompeius' defeat by Viriathus and his notorious foedus with the Numantines». The specific reference to the Roman administrative divisions may indicate that the statement of Charax ultimately derives from a good source. But the Greek (with correct punctuation by Jacoby) should mean that "Quintus» was $\pi 0 \lambda \varepsilon ́ \mu \alpha \rho \chi \circ \varsigma$ in both Spanish prouinciae, rather than that he was defeated by Viriathus in both Citerior and Ulterior. Charax must simply be mistaken, since the Spains were always two prouinciae in the war with Viriathus. We need not accept Richardson's forced interpretation of the passage. A "Quintus" who can be said to have made a treaty with Viriathus is readily available: Q. Fabius Maximus Servilianus, cos. 142 (and pro cos. 141) in Hispania Ulterior.

Even with Richardson's punctuation of the Charax passage, Q. Servilianus remains the best possible identification. Though Servilianus' main activities do seem to have been in Baeturia (i.e. Ulterior), there is no telling whether he in fact fought in both Spanish prouinciae. The Roman consul suffered a rout at the hands of Viriathus when he first arrived in Spain and was marching to the relief of Itucca $(I b .67,284)$, and then a second defeat at the town of Erisane, which led to the actual treaty with the Lusitanian commander $(I b .69,292)$. The common equation of Erisane with Arsa in Baeturia (on which see Rubinsohn, $R S A 11,1981$, p. 198, n. 195) is only a guess: no identification is ventured by A. Tovar, Iberische Landeskunde II 1, Baden-Baden 1974, p. 183. Either of these defeats (particularly the first) can have been in Citerior. Hence Charax's mistake. 